chemistry at Armstrong (now King's) College, Newcastle upon Tyne. At Easter 1920, he succeeded the late Prof. Crossley as Daniell professor of chemistry, King's College, London, where he remained until his retirement in 1938 .

During the First World War, he was engaged upon problems connected with tracer ammunition, and for these services received the O.B.E. in 1918. In that year also he was elected a Fellow of the Royal Society. He was a Fellow of both University College and King's College, London, and an honorary D.Sc. of Queen's University, Belfast.

Prof. Smiles rendered considerable service to the chartered chemical bodies. A Fellow of the Chemical Society from 1898, he served as secretary during 1912-20, and was a vice-president during 1920-23. $\mathrm{He}$ became a Fellow of the Royal Institute of Chemistry in 1916, was examiner in general chemistry for the associateship during 1920-24, and a member of Council during 1931-35 and 1936-39.

In 1920 he married Minnie, youngest daughter of the late G. N. Patterson, of Newcastle, who survives him. During most of the war and post-war period, Prof. and Mrs. Smiles lived at Inverness, but had quite recently returned to Tunbridge Wells, where they had resided during his tenure of the King's College professorship.

Almost all Prof. Smiles's published papers, numbering more than a hundred, are concerned with organic compounds of sulphur (or selenium). The only exceptions are those with Moissan on silicon and silicon hydrides; that with Knorr on $\beta$-methylmorphimethine; and his last three papers. His studies touched on many different types of sulphur compounds, including sulphonium bases, sulphoxides, sulphinic and sulphenic acid derivatives and cyclic compounds. Typical investigations were those on disulphoxides, which were shown to be thiolsulphonic esters; and on the two isomeric sulphides of $\beta$-naphthol. As early as 1911 , he had been interested in the problem presented by the $\beta$-naphthol sulphides; with his collaborators he elucidated it in a long series of papers, and showed the interconversion of the two compounds to be a special example of what came to be called 'the Smiles' rearrangement'. His last three papers were concerned with other examples (not sulphur compounds), including aryl salicylates and o-carbamyl derivatives of diphenyl ether. Appropriately, all this work was adequately summarized, just after Prof. Smiles's retirement, in the Annual Report on the Progress of Chemistry (36, 197; 1939).

Except the work published with Moissan in the Comptes rendus of the Paris Academy of Sciences and a few papers in the Berichte, all Prof. Smiles's papers appeared in the Journal of the Chemical Society, its Proceedings and Transactions. His only published book was "The Relations between Chemical Constitution and some Physical Properties", published in 1910. It was never reprinted and copies are not easy to come by. Although progress both of accumulation of data and of underlying theory has left the book behind, it still has interest as an introduction to its subject.

Valuable as his research work was, it is even more as a teacher that Prof. Smiles will be remembered. In the period 1917-19 at University College, he lectured on systematic inorganic chemistry as well as organic, and at King's College he always maintained the excellent practice of lecturing on inorganic chemistry to the first-year students. He was accustomed to say himself that one of the most difficult tasks of those in academic life was to maintain a proper balance between research and the teaching and training of students. In his later years, he tended to shift the balance towards the teaching side, and indeed to regard research as a part of student training. He came to have a fine reputation as a teacher, and to have been a student under Smiles was a recommendation in itself.

His interest in his students did not stop short with their academic life; he was a kind and wise adviser on their choice of employment, and took a deep and practical interest in their subsequent careers. The affection and esteem in which he was held by his old students and colleagues were evident on his retirement, and are simply expressed by the inscription in the watch which they presented to him in the autumn of 1938 : "Samuel Smiles-Teacher and Friend".

Reginald Child

\section{Prof. A. Mittasch}

ON June 4 last, Prof. Alwin Mittasch died in Heidelberg in his eighty-third year. He started as a chemist, studied the then mysterious phenomenon of catalysis under Ostwald and was later commissioned by Carl Bosch in Ludwigshafen to find a method of putting into commercial production Fritz Haber's experiments on the catalytic formation of ammonia from nitrogen and hydrogen. In this he was fully successful. Later he broadened his studies and thoughts about catalysis so considerably that in 1948 he published a book under the title, "Von der Chemie zur Philosophie". The philosophical aspect of catalysis is release (Auslösung)-a relation between cause and effect which does not obey energetic laws, such as, for example, the action of the will. These trains of thought brought Mittasch into contact with Robert Mayer, and he published a great number of essays dealing with Mayer's writings. In the last year of his life Mittasch published two books of considerable importance-"Friedrich Nietzsche als Naturphilosoph" and, quite recently, "Erlösung und Vollendung". Mittasch enjoyed the rather exceptional honour of being made member of the Heidelberg Academy of Science without being a university professor, but, on the occasion of his eightieth birthday, the title professor was awarded to him. Up to his last illness, which led to his death within a few weeks, the old scholar was in the full possession of his mental powers and incessantly busy writing articles and answering, mostly by return mail, the letters of a wide circle of friends which his enthusiastic temperament and his kind nature attracted to him.

\section{Miss Henrietta Jex-Blake}

Mrss Henrietta Jex-Blake, who died on May 21 at the age of ninety, was principal of Lady Margaret Hall, Oxford, during 1909-21. Her father was Dr. T. W. Jex-Blake, Dean of Wells and formerly headmaster of Rugby. After being headmistress of St. Margaret's, Polmont, from 1889 until 1909 she succeeded Dame Elizabeth Wordsworth, the first principal of the Hall, who had held office for thirty years.

The demand among women for an Oxford education had, throughout the Hall's history, led to a steady expansion in its numbers, and Miss Jex-Blake's term of office coincided with a marked increase in this demand. Under her a considerable building pro- 
gramme was carried out, in defiance of shortage of funds, and the Toynbee Building, designed by Sir Reginald Blomfield, was opened in 1914, bringing the accommodation for undergraduates up to eighty. Her principalship covered the difficult years of the First World War, and, following them, the culmination in 1920 of the long struggle for the opening of Oxford degrees to women. Miss Jex-Blake had the satisfaction of receiving the M.A. herself at the first degree ceremony in October 1920, and then of presenting a steady stream of her former students at successive ceremonies until her retirement in 1921 .

In 1926 she was elected an honorary Fellow of the Hall. After her retirement she lived with her sister, formerly Mistress of Girton, first in London and then in Kent.

Miss Jex-Blake and her sisters had received an excellent education in the home under her father's care and was a good linguist, a highly accomplished musician and was widely read in the literature of several countries. She had travelled widely, particularly in France, Spain and Italy. She was in all her ways a lady of the old-fashioned kind, selfdisciplined and imposing a high standard of conduct on herself and others. Though somewhat shy and reserved, she was most generous to those in need or trouble, and many members of the Hall owed much to her carefully concealed assistance. A graduate studentship at Lady Margaret Hall bearing her name has been formed from capital provided by her.

WE regret to announce the following deaths :

Lieut.-General Sir William Furse, K.C.B., K.C.M.G., director of the Imperial Institute, London, during $1926-34$, on May 31, aged eighty-eight.

Sir Thomas Hunter, K.B.E., emeritus principal of Victoria University College, Wellington, and vicechancellor during 1929-47 of the University of New Zealand, aged seventy-six.

M. Camille Raveau, editing secretary of the Comptes rendus of the Paris Academy of Sciences during 1904-46 and known also for his work in the field of thermodynamics, on April 15, aged eighty-six.

\section{NEWS and VIEWS}

Applied Mathematics at Swansea: Prof. J. G. Oldroyd

Dr. J. G. OLDRoyd has been appointed to the recently created chair in applied mathematics in the University College of Swansea. This post is within the Department of Mathematics, under the direction of Prof. R. Wilson, and the holder of the new chair will be responsible for teaching and research in applied mathematics in the College and will have his own staff for the purpose. Dr. Oldroyd has had a distinguished academic career. He was educated at the Bradford Grammar School and was a scholar of Trinity College, Cambridge. He was a Wrangler in 1941 and was awarded a distinction in Part III of the Mathematical Tripos in 1942 ; during this period he obtained the Rouse Ball, Mathison and Mayhew Prizes. In 1942 he entered the Projectile Development Establishment at Boncath, Cardiganshire, and remained there until 1945, when he joined the laboratory for fundamental research of Messrs. Courtaulds, Ltd., as a mathematical physicist. At their request he spent a year in research studies at Trinity College, Cambridge, and while still with Messrs. Courtaulds was elected to a research fellowship of Trinity College for the period 1947-51. He is honorary treasurer of the British Society of Rheology and of the Second International Congress on Rheology. $\mathrm{He}$ is also a member of the weapons research panel of the Ministry of Supply. His numerous publications relate to the theory of viscous flow, plastic flow and finite elastic deformation, especially in materials which have both viscous and elastic properties combined. His experience in these fields may be of help to the local industries at Swansea, which include the refining and circulation of oil products and the working of molten steel. Dr. Oldroyd's work will be of great interest to the Physical Science Departments and, in particular, to the Departments of Engineering and Metallurgy in the College.

\section{New Nature Reserves in Britain}

Following its declaration last summer as a national Nature reserve of 100 acres forming part of a small chalk coomb on the southern edge of the South
Downs, some four miles north-west of Chichester, the Nature Conservancy has now added a further 100 acres to its Kingley Vale Nature Reserve, which nearly completes the acquisition of the natural yew woods, some of the trees of which are very old. About 76 acres, known as Mincing Wood and Crawford's Rough, of the extensive woodlands near Blean, Kent, have also been acquired by the Conservancy, and are being declared a national Nature reserve. The woods include sessile oak with hazel and hornbeam coppice, chestnut and birch, and contain a variety of unusual plants. The importance and value of the reserve are greatly increased by the presence of a species of butterfly, the heath fritillary, which occurs here and practically nowhere else in Britain, though its food plant (a semi-parasitic species) is well distributed elsewhere. Monk's Wood, about 375 acres of woodland, some five miles north-east of Huntingdon, has also been acquired and declared a Nature reserve. The area is the last of the few remaining examples of the ancient ash-oak woodland of the heavy Huntingdonshire clays, and is a classic locality for the characteristic fauna of such woodland, containing rare plants as well as rare insects. Although the wood was largely cut down during the First World War, natural regeneration has allowed the persistence of the most characteristic species. A further 84 acres, known as Barrow Wood, and part of the wood known as Hibbet's Wood, have been added to the 155 acres declared as the Ham Street Woods Reserve, Kent, in May 1952. This type of woodland-standards with coppice-is declining in this neighbourhood, and the Wild Life Conservation Special Committee recommended that samples of this type of woodland with its characteristic flora should be maintained to preserve the rich insect fauna, including species that seem to be disappearing or to have disappeared from other similar woods.

\section{American Aid for Industrial and Technological Research in Britain}

ARRANGEMEnTs for the expenditure of counterpart. funds, amounting to nine million dollars, derived from the United States Economic Aid under 